\title{
Eating behavior of preschool-age children during social distancing period due to COVID-19
}

\author{
Comportamento alimentar de crianças em idade pré-escolar durante o períodlo de distanciamento \\ social devido ao COVID-19 \\ Comportamiento de alimentación de niños en edad preescolar durante el período de distaciamento \\ social debido a COVID-19
}

Received: 10/28/2021 | Reviewed: 11/11/2021 | Accept: 11/17/2021| Published: 12/20/2021

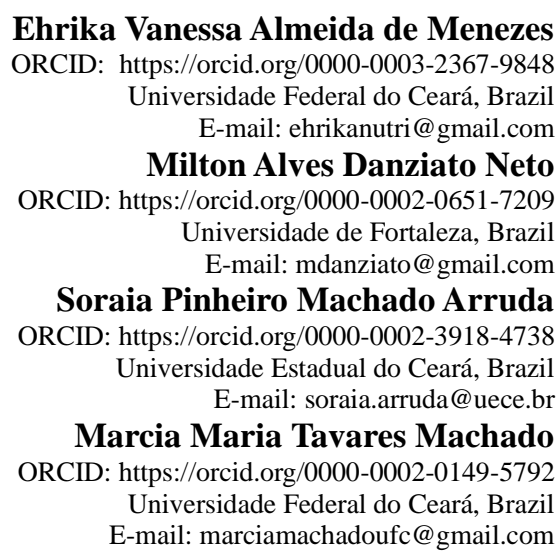

\begin{abstract}
The aim of the study was to investigate the eating behavior of preschool children during the social isolation period of the first wave of COVID-19 in Fortaleza, Ceará. This is a cross-sectional observational study, carried out with caregivers of preschool children aged from 2 to 6 years. The PENSE questionnaire (IBGE) was used to collect socioeconomic data and the data referring to eating behavior was used the CEBQ. 286 parents (mother and father) and their children participated in the research, of which $53.8 \%$ were female. The preschoolers in the study constituted $5.2 \%$ of infant I, 9.8\% infant II, 14.7\% infant III, 20.6\% infant IV, 23.1\% infant V, 15.4\% 1-year elementary school and $11.2 \%$ did not attend school. As for the education of most mothers, $83.9 \%$ completed higher education. Regarding the number of people who lived in the household, $44.4 \%$ lived with 4 people and $73.1 \%$ had 1 child. The highest mean values are present in the dimension "Pleasure to eat" (EF) and "Response to satiety" (SR), while the lowest refer to the dimensions "About Emotional Intake" (EOE) and "Response to food" (FR). The statistical results of the "Food Fussiness" (FF) subscale point out important aspects about the selectivity in the sample of the present study, demonstrating a good tendency to picky eating. The dimension with the lowest mean was "Emotional Overeating", demonstrating that when confined due to the COVID-19 pandemic, preschoolers still have EOE lower than all other subscales. It follows that children in preschool stage have presented a higher prevalence in subscales that are linked to food avoidance behavior.
\end{abstract}

Keywords: Feeding behavior; Preschool; COVID-19, Children.

\section{Resumo}

O objetivo do estudo foi investigar o comportamento alimentar de pré-escolares durante o período de isolamento social da primeira onda de COVID-19 em Fortaleza, Ceará. Trata-se de um estudo tipo transversal observacional, realizado com cuidadores de crianças pré-escolares na faixa etária de 2 a 6 anos. Utilizou-se o questionário PENSE (IBGE) para coletar dados sócio econômicos e os dados referentes ao comportamento alimentar utilizou-se o CEBQ. Participaram da pesquisa 286 pais (mãe e pai) e respectivos filhos, dos quais 53,8\% eram do sexo feminino. Os préescolares do estudo constituíam 5,2\% do infantil I, 9,8\% infantil II, 14,7\% infantil III, 20,6\% infantil IV, 23,1\% infantil V, 15,4\% 1 ano do ensino fundamental e $11,2 \%$ não frequentavam a escola. Quanto a escolaridade das mães a maioria, 83,9\% concluiu o ensino superior completo. Em relação ao número de pessoas que residiam no domicílio 44,4\% moram com 4 pessoas e 73,1\% tinham 1 filho. Os valores médios mais elevados estão presentes na dimensão "Prazer em comer" (EF) e "Resposta à saciedade" (SR), enquanto os mais baixos se referem às dimensões "Sobre 
ingestão Emocional" (EOE) e "Resposta à comida" (FR). Os resultados estatísticos da subescala "seletividade" (FF) apontam aspectos importantes sobre a seletividade na amostra do presente estudo demonstrando uma boa tendência ao comer exigente. A dimensão com a menor média foi a "Sobreingestão emocional" demonstrando que quando confinadas devido à pandemia da COVID-19, pré-escolares ainda apresentam EOE inferior a todas outras subescalas. Conclui-se que as crianças pré-escolares apresentaram maior prevalência nas escalas que evitam o alimento.

Palavras-chave: Comportamento alimentar; Pré-escolar; COVID-19; Criança.

\section{Resumen}

El objetivo del estudio fue investigar la conducta alimentaria de los niños en edad preescolar durante el período de aislamiento social de la primera ola de COVID-19 en Fortaleza, Ceará. Se trata de un estudio observacional transversal, realizado con cuidadores de niños en edad preescolar de 2 a 6 años. Para la recogida de datos socioeconómicos se utilizó el cuestionario PENSE (IBGE) y los datos referentes a la conducta alimentaria se utilizó el CEBQ. En la investigación participaron 286 padres (madre y padre) y sus hijos, de los cuales el 53,8\% eran mujeres. Los preescolares del estudio constituyeron el 5,2\% de Infantil I, 9,8\% Infantil II, 14,7\% Infantil III, 20,6\% Infantil IV, $23,1 \%$ Infantil V, 15,4\% 1 año de primaria y 11,2\% no asistieron a la escuela. En cuanto a la educación de la mayoría de las madres, el 83,9\% completó la educación superior. En cuanto al número de personas que vivían en el hogar, el 44,4\% vivía con 4 personas y el 73,1\% tenía 1 hijo. Los valores medios más altos están presentes en la dimensión "Placer de comer" (FE) y "Respuesta a la saciedad" (SR), mientras que los más bajos se refieren a las dimensiones "Acerca de la ingesta emocional" (EOE) y "Respuesta a la comida". (FR). Los resultados estadísticos de la subescala "selectividad" (FF) señalan aspectos importantes sobre la selectividad en la muestra del presente estudio, demostrando una buena tendencia al capricho alimentario. La dimensión con menor media fue la "Sobreingestión emocional", demostrando que en confinamiento debido a la pandemia de COVID-19, los niños en edad preescolar todavía tienen EOE más bajo que todas las demás subescalas. De ello se desprende que los niños em etapa pré-escolar han presentado una mayor prevalencia em las subescalas que se relacionan con la conducta de evitación alimentaria.

Palabras clave: Conducta alimentaria; Pré-escolar; COVID-19; Niños.

\section{Introduction}

The disease caused by the new Coronavirus - 2019, popularly known as COVID-19, which was firstly mentioned in Wuhan, China, in December 2019, and quickly spread around the world, has resulted in a global health crisis. Children represent one to five percent of the diagnosed cases of COVID-19, however some children who may be infected, may be asymptomatic and, therefore, not diagnosed. (Ludvigsson, 2020)

In this scenario of COVID-19 pandemic, public health recommendations and government measures have enforced lockdown, restricting movement and physical contact between people and creating social isolation. Although restrictions have helped to reduce infection rates, these limitations have also caused negative effects, since they have restricted daily physical exercises and leisure activities. (Hossain; Sultana; Purohit, 2020). This new reality of social and physical distancing has caused some impacts due to the fact that children had to stop going to school and, at the same time, some parents lost their jobs or started working from home. The economic consequences of the COVID-19 pandemic as well as the control measures put in place have led to increased levels of psychological distress and uncertainties which may affect parents' behaviors, leading to parental behaviors that are more authoritarian, strict, and not affective, ultimately impacting the quality of family life. (Prime; Wade; Browne, 2020)

Children's eating behavior must be seen as a systemic mode, because it is related to parental, cultural and socioeconomic environment. Behaviors and familiar decisions that are authoritarian and uncontrolled may trigger eating disorders, causing obesity or malnutrition resulting from impulsiveness, responsiveness, and autonomy. Therefore, environmental changes that modify lifestyle habits may be positive or negative, so, it is necessary to pay attention to the relationship established with kids since their first years of life, mainly after they start preschool, as it is when children become more active (Scaglioni et al., 2018; Taylor \& Emmet, 2018)

Changes in the family environment resulting from the lockdown have resulted in disruptions to children's daily routines and activities. Emerging research indicates that changes in the family environment in the context of the COVID-19 
pandemic has adversely impacted the eating and physical activity behaviors of children. Changes in children's eating and dietary patterns, and physical activity and sedentary levels and behaviors have resulted in increased increased risk of excess weight gain (Carrol et al., 2020; Sidor \& Rzymski, 2020). For example, a study by LIPPI and colleagues found that being in closed spaces resulted in children's increased screentime (e.g., online games use of social media), which may adversely increase risk of psychological disorders, musculoskeletal disease, and neurological complications. (Lippi et al., 2020).

Previous studies have reported that young individuals have difficulty with weight-control lifestyle programs while at home compared to when they are in their usual school curriculum (Rudle et al., 2020). Furthermore, recent observations show that during the lockdown, many households consumed more ultra-processed and calorie-dense foods than usual (Creswell,2021).

Parents play a central role in creating and maintaining a family environment that impacts their children's eating and physical activity behaviors. Parents create family eating environments that shape their children's access and experiences with foods and eating (Lindsay et al., 2006). The social isolation and economic uncertainties brought by the COVID-19 pandemic may negatively impact parents' mental health and parenting practices, ultimately affecting the family eating environment and children's daily routines and eating behaviors. Therefore, the aim of this study was to assess eating behaviors duringthe social distancing and lockdown resulting from the first wave of the COVID-19 pandemic among preschool-age children in Fortaleza, Ceará.

\section{Methodology}

\section{Study Design}

This is a cross-sectional study conducted from August to September in 2020 in Fortaleza, the capital of the state of Ceará, Northeast Brazil. In 2020, Fortaleza had approximately 2.669.342 inhabitants with 274.142 children from 0 to 5 years old, which represented $10,27 \%$ of the population (IBGE, 2020).

\section{Study Sample}

A convenience sample of parents of preschool-age children (2 to 6 years) were recruited to participate in the study. Sample size was calculated based on sample calculator. In order to define the sample, it was used a calculation/ equation that was suitable to develop the calculation of the finite population size (Hulley et al., 2014). During the sample calculation, the following equation parameters were used to estimate the sample: study confidence coefficient of 99\% ( $Z=2,575)$; sampling error of 3\% (e=0,03); and children population size of 274.142 (IBGE, 2019). In terms of the event prevalence, it was regarded the value of $50 \%(\mathrm{p}=0,5)$ as an average prevalence to different indicators, because of the lack of knowledge about the event proportion. The equation has shown that it is necessary to have a sample of 229 participants considering the parameters established.

\section{Data Collection}

Parents were recruited to participate in this study using the "snowball" model when a family indicated another family that had children in school.Data was collected using an on-line questionnaire in Google forms and sent to students' parents (public and private school) in Whatsapp groups.

The questions related to socioeconomic information were based on National School Health Survey (PeNSE), which was applied in 2015 by IBGE. The parents of the children were asked about their level of education, the number of children living in the house who were at school, the number of bathrooms in the house, property holding and if domestic service was 
provided in their houses. To evaluate the eating behavior, it was used Children's Eating Behavior Questionnaire (CEBQ), which was created considering the current knowledge about nutritional causes of obesity, focusing on behavioral determinants. This questionnaire investigates CEBQ, eating behavior and it can also be used to plan behavioral strategies to interfere in obesity.

The CEBQ questionnaire, validated to Portuguese (Viana \& Sinde, 2008), includes 35 items that aim to evaluate eight dimensions associated to children's obesity. These dimensions of factors are: a) Food Responsiveness (FR) - it is about the influence of external factors (for example: social factors) in the appetite and food intake; b) Enjoyment of food (EF) - it is about children's interest in food; c) Satiety responsiveness (SR) - it is related to the appetite control; d) Slowness in eating (SE) - It is related to the lack of interest in food; e) Food Fussiness (FF) - it is the preference for a limited group of food; f) Emotional over-eating (EOE) - it is about the influence of emotional factors in the increase of food intake; g) Emotional under-eating (EUE) - emotional factors may decrease food intake; h) Desire for drinks (DD) - the interest in sweetened drinks, such as soda and juice.

The answers were evaluated in scale like Likert, which has five points that vary from 1 (not often) to 5 (very frequent). The items 3, 4, 10, 16 and 32 are in a reverse scale. The scores of the questions that belong to the same dimension are added up. In each dimension analyzed will have an average value and standard deviation (Viana\& Sinde, 2008).

The questions were gathered according to the analyzed dimension: question 12,14,19,28 and 34 were about Food Responsiveness; 1, 3, 20 and 22 were related to enjoyment of food; Satiety Responsiveness - 3, 17, 21, 26 and 30; Slowness in eating - 4, 8, 18 and 35; Food Fussiness - 7, 10, 16, 24, 32 and 33; Emotional over-eating - 2, 13, 15 and 27; Emotional undereating - 9, 11, 23 and 25; and Desire for drinks - 6, 29 and 31. Besides the subscales that were described, it was considered two groups that are associated to the subscales. The first group is about the behavior that shows attraction for food, it includes the following subscales: EF, RF, EOE and DD. The second group is related to the avoidance of food, which is consisting by SR, SE, FF and EUE. The result of these dimensions showed the way someone interacts with food, thus, this reflects a pattern or eating style that influences nutritional states.

In Google forms questionnaire all the questions were considered mandatory, thus the answers could only be submitted if the participant had answered all of them. The project was approved by the ethics committee of the Federal University of Ceara No. 36223020.3.0000.5054. All participants signed the Informed Consent Form, sent via the link to the questionnaire applied by Google Forms.

\section{Data Analysis (Missing information)}

Data entered in an Excel sheet and analyzed in Stata SE 14.0. The descriptive statistics was used to define the proportion of responses to each question and the total of scores that was distributed in each questionnaire.

\section{Results and Discussion}

286 parents and school-age children were interviewed in Fortaleza, Northeast Brazil. 53,8\% of them were female. $83,9 \%$ had the higher education level of education and 3,5\% did not have a school diploma. Concerning the number of people who lives in the house, $44,4 \%$ of them live with 4 people; $23,3 \%$ live with 3 people and $18,2 \%$ live with 5 people. The number of children each mother has was about $1(73,1 \%)$ and $2(25,5 \%)$.

The children who participated in this study were separated in the following level of schooling: 15 (5,2\%) preschool education (level 1); 28 (9,8\%) preschool education (level 2); 42 (14,7\%) preschool education (level 3); 59 (20,6\%) preschool 
education (level 4); $66(23,1 \%)$ preschool education (level 5); $44(15,4 \%)$ first grade of elementary school and $11,2 \%$ of the kids did not go to school.

Table 1 shows the minimum, maximum, median, average and standard deviation of each dimension about children's eating behavior.

Table 1. Descriptive statistics related CEBQ's dimensions.

\begin{tabular}{ccccc}
\hline CEBQ's dimensions & $\begin{array}{c}\text { Mini- } \\
\text { Max }\end{array}$ & Medians & Average & Standard deviation \\
\hline Food Responsiveness (FR) & $2,64-3,6$ & 3,2 & 3,12 & 0,48 \\
Slowness in eating (SE) & $2,44-3,44$ & 3 & 2,94 & 0,5 \\
Food Fussiness (FF) & $2,57-3,23$ & 2,83 & 2,9 & 0,33 \\
Satiety responsiveness (FR) & $1,64-3,26$ & 2,4 & 2,45 & 0,81 \\
Enjoyment of food (EF) & $2,49-4,01$ & 3,25 & 3,25 & 0,76 \\
Desire for drinks (DD) & $1,4-3,52$ & 2,33 & 2,46 & 1,06 \\
Emotional over-eating (EOE) & $1,28-2,92$ & 2 & 2,1 & 0,82 \\
Emotional under-eating (EUE) & $2,09-3,69$ & 3 & 2,89 & 0,8 \\
\hline
\end{tabular}

Source: Prepared by the authors.

Picture 1 demonstrates the average answer of each question, considering each CEBQ's dimension.

Picture 1. Average answers of each question, considering each CEBQ's dimension.
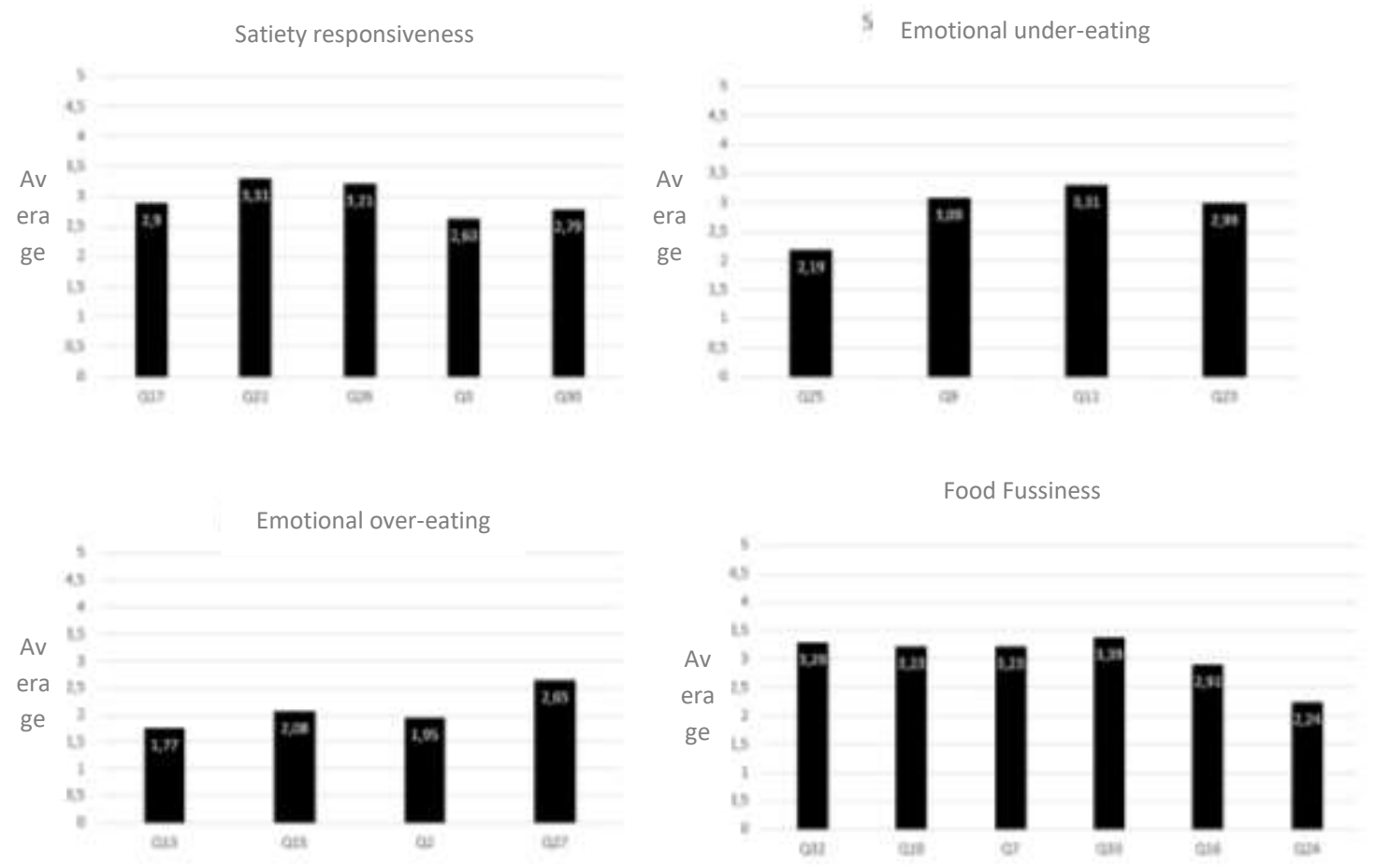

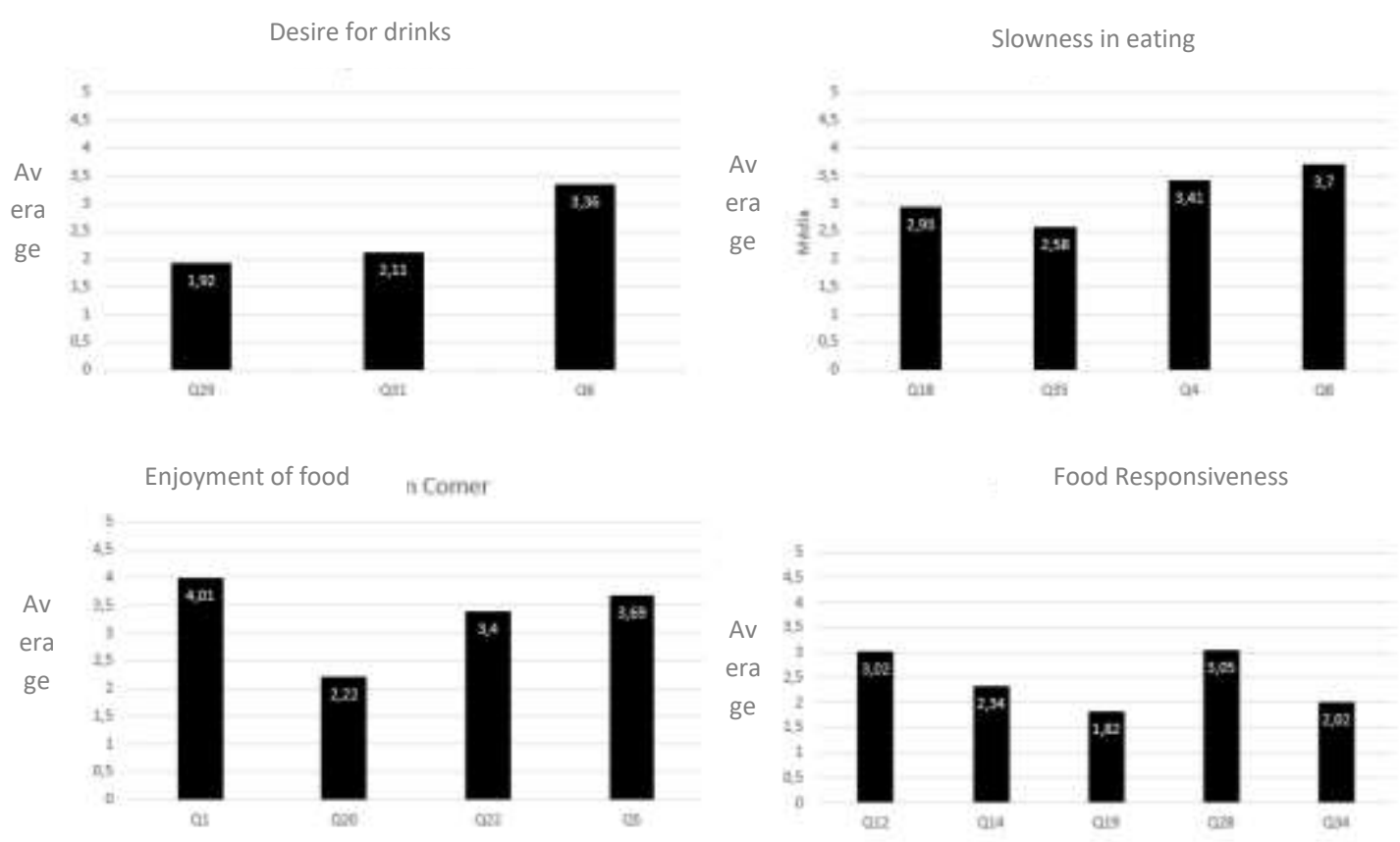

Source: Prepared by the authors.

The highest average scores are in the dimensions "Enjoyment of food" (EF) and "Satiety responsiveness" (SR). On the other hand, the lowest average scores are in the dimension "Emotional over-eating" (EOE) and "Food Responsiveness" (FR).

Table 2 presents Pearson correlation analysis of eating behavior dimensions, according to the medians of each dimension and gender.

Table 2. Correlation between the medians related to eating behavior dimensions according to gender.

\begin{tabular}{|c|c|c|c|c|c|}
\hline \multirow{2}{*}{ Dimensions } & & \multicolumn{2}{|c|}{ Gender } & \multirow{2}{*}{$\mathbf{X}^{2}$} & \multirow{2}{*}{$\operatorname{Pr}$} \\
\hline & & Female $(\%)$ & Male (\%) & & \\
\hline \multirow{2}{*}{ Food Responsiveness } & 1 & 48,39 & 49,62 & \multirow{2}{*}{0,0431} & \multirow{2}{*}{0,836} \\
\hline & 2 & 51,61 & 50,38 & & \\
\hline \multirow{2}{*}{ Enjoyment of food } & 1 & 54,19 & 50,38 & \multirow{2}{*}{0,4136} & \multirow{2}{*}{0,52} \\
\hline & 2 & 45,81 & 49,32 & & \\
\hline \multirow{2}{*}{$\begin{array}{l}\text { Satiety } \\
\text { responsiveness }\end{array}$} & 1 & 45,81 & 48,56 & \multirow{2}{*}{0,0164} & \multirow{2}{*}{0,898} \\
\hline & 2 & 54,19 & 53,44 & & \\
\hline \multirow{2}{*}{ Enjoyment of food } & 1 & 66,23 & 59,54 & \multirow{2}{*}{1,36} & \multirow{2}{*}{0,243} \\
\hline & 2 & 33,77 & 50,46 & & \\
\hline \multirow{2}{*}{ Food Fussiness } & 1 & 29,03 & 34,35 & \multirow{2}{*}{0,9313} & \multirow{2}{*}{0,335} \\
\hline & 2 & 70,97 & 65,65 & & \\
\hline \multirow{2}{*}{ Emotional over-eating } & 1 & 59,35 & 52,67 & \multirow{2}{*}{1,2888} & \multirow{2}{*}{0,256} \\
\hline & 2 & 40,65 & 47,33 & & \\
\hline \multirow{2}{*}{$\begin{array}{l}\text { Emotional under- } \\
\text { eating }\end{array}$} & 1 & 61,94 & 54,96 & \multirow{2}{*}{1,4246} & \multirow{2}{*}{0,233} \\
\hline & 2 & 38,06 & 45,04 & & \\
\hline \multirow{2}{*}{ Desire for drinks } & 1 & 49,68 & 49,62 & \multirow{2}{*}{0,0001} & \multirow{2}{*}{0,992} \\
\hline & 2 & 50,32 & 50,38 & & \\
\hline
\end{tabular}

$* 1$ - score $<$ median related to the analyzed dimension. $* 2$ - score $>$ median related to the analyzed dimension.

Source: Prepared by the authors. 
In accordance with Pearson correlation analysis, it is possible to determine that there is no meaningful difference between the studied eating behavior's dimensions and children's gender.

When the group of scales that constitutes CEBQ was investigated separately, the authors have decided to separate the dimensions in different groups. There is the group that evaluates "Food attraction", which includes the dimension EF (Enjoyment of food), FR (Food Responsiveness), EOE (Emotional over-eating) and DD (Desire for drinks). The other group studies the behavior related to "food avoidance", and it is constitutes by the following dimensions: SR (Satiety responsiveness), SE (Slowness in eating), FF (Food Fussiness) and EUE (Emotional under-eating). The data of each group are presented in Table 3.

Table 3. Descriptive statistics related to CEBQ group dimensions.

\begin{tabular}{cccc}
\hline Groups of CEBQ & Min-Max & Medium & $\begin{array}{c}\text { Standard } \\
\text { deviation }\end{array}$ \\
\hline Food attraction (EF, RF, EOE, DD) & $2,11-3,33$ & 2,53 & 0,54 \\
Food avoidance (SR, SE, FF, EUE) & $2,46-3,15$ & 2,9 & 0,3 \\
\hline
\end{tabular}

Source: Prepared by the authors.

According to the datas analysis, it was observed that preschoolers have a tendency to avoid food, since they present high levels of satiety responsiveness, which may also highlights the presence of food selectivity.

Preschoolers lifestyle is strongly influenced by parents, however, these interferences occur not only because of family, they are also associated to children's interaction with media, and the information it communicates. Nevertheless, the majority of participation, control and food intervention come from parents' imposition. Thus, CEBQ is a tool that enables to describe children's eating behavior from parents perspective, identifying the factors that cause more impact in their subscales (Wardle et al., 2001; Vitorino, 2018).

This study aimed to verify which CEBQ's dimensions have more influence in children who are in distancing isolation, considering that an unusual situation. This context may affect not only kids' nutrition, but it can also be linked to other kinds of negative conditions, such as disease susceptibility, especially in the pandemic scenario.

The restrictive environment created by COVID-19 has aggravated parents and kids' mental health and well-being. Behavioral and mood changes tend to be negative, because they are caused by psychological disorders that are originated from social distancing. (Courtney et al., 2020; Gassman_pines et al., 2020). Blisset et al., (2019) evaluated that "Enjoyment of food" is higher when children has a neutral mood or when they are induced to bad mood, the same happens with the population that was investigated in this research, it is also relevant to emphasized that this dimension had the highest average in the sample. Besides that, Blisset et al., (2019) realized that a higher number of calorie intake is related to EF subscale in all analyzed categories, according to the food that was offered in their research. This relation is also found in the study of Carnell et al. (2016) with preschoolers, showing a strong correlation.

"Satiety responsiveness" was the second highest average in the sample. However, according to Blisset et al., (2019), this result is not associated to bad mood, but it is related to Emotional under-eating. Carnell et al. (2016), in their study, observed that there is a high level of SR linked to low food intake, when it was served five different kinds of meals to preschoolers. In addition, there is a huge number of studies that shows a negative relation between SR and overweight and body measure, which supports the ideia that a decrease in this scale avoids the control of food intake and this fact contributes to gain weight. (Passos et al., 2015; Derks et al., 2018; Dalrymple, 2019; Spahic, 2019) 
Fussy eating is connected to a lot of experiences and emotions that kids experience, however, factor genic also interferes in eating decisions (Wolstenholme et al., 2020). Cole et al., (2017), through a systematic review, discovered an increase of 0,06 units in Food Fussiness (FF) in each month of life during one year in 30 month-old children, their study did not associate this result to gender and weight. Besides that, there is an inverted correlation between FF and the quantity of food intake, being vegetables, in particular, the food category more undesirable according to FF (the higher the FF is, the more undesirable this food category is (Cole et al., 2017; Fernandez el at., 2018; Sandvik et al., 2019). The statistic results of FF subscale indicate important aspects about fussiness in this study, because it had a high average and it also had the lowest score variation. This fact demonstrates that there is a tendency to fussy eating in the group analyzed.

Emotional overeating dimension presented the lowest average in a several studies with preschoolers, and it had no relation to their nutritional state. When these children are in social isolation, due to COVID-19 pandemic, the EOE is lower than the other scales. To compensate this, EF and SR are the highest subscales (Konings et al., 2018; Blissett et al., 2019; Sandvik et al., 2019; Kininmonth et al., 2020; Joseph Louis, \& Tyug, 2021). This reveals that, at this age, children did not create a lot of emotional bonds with food to overcompensate, on the other hand, they demonstrate a great pleasure in food intake. In the same way, children have already presented good signs of Satiety responsiveness or food rejection, since they do not understand their needs, which is why they avoid some kinds of meals.

It was not possible to meet and monitor the participants face-to face during pandemic period, thus, the data related to weight and height were not obtained. Nonetheless, Pedrosa (2017) has shown, through a big sample, that the decrease in malnutrition and overweight/ obesity in children are connected to mother's schooling level, so the higher the mother's school level is, the higher children's BMI will be. The high percentage of mothers with university degree $(83,9 \%)$, in this study, may be an indication that this research has a huge number of children with BMI above eutrophic intervals, considering the restrictive population. According to IBGE (2019), more than half of the adult population in Brazil do not complete high school, and this number is higher in northeast region.

Many children suffer pressure to eat some kinds of food that are considered healthy (fruit, dairy products, vegetables) by their parents. A consequence of this pressure is the tendency to create negative behaviors and the decrease of children's ponderal state. Besides that, the restriction of some food or group of food might cause gain weight, in other words, it has an adverse effect (Coelho et al., 2017).

Contrary to this hypothesis, it was observed that the group "Food avoidance" dimension exceeded "Food attraction". In addition, the subscale EOE was the best, which was not what had been expected, since many studies associate this subscale to overweigh and obesity. According to Spahić and Pranjić (2018) and Passos et al. (2015), children with higher scales in the group "Food Attraction" have higher Body Mass Index. Konings et al. (2018) have found the same dependence with preschoolers. Derks et al. (2018) associated EOE to higher values of Body Mass Index and fat mass. Thus, although there is logic in these comparisons, it is not trivial to establish solid connections that are based only on these parameters, without considering weight and height.

Eating habits are formed in childhood and someone's eating behavior is related to the kind of food this person had contact during childhood and to the kind of food parents ate. Food preferences may have consequences in adult life, influencing the nutritional state (Ribeiro, 2017).

\section{Conclusion}

Children in preschool stage have presented a higher prevalence in subscales that are linked to food avoidance behavior (Satiety responsiveness -SR, Slowness in eating - SE, Fussiness - FF and Emotional under-eating - EUE. 
These children also had a tendency to avoid food, showing high levels in Satiety responsiveness, which may demonstrate that there is food selectivity.

This study has some limitations. This study was carried out in the period right after the 1st lockdown decreed by the state government, due to the high prevalence of covid-19 cases. The study was conducted remotely/online and does not represent children from Fortaleza. The fact that the questionnaire was answered by women with a high level of education presents a bias, since women living in neighborhoods with a lower HDI were not questioned.

Researches about nutritional state, especially the ones associated to deficit in children's growth, might be stimulated, due to the fact that a long time of malnutrition may influence children's development, especially at this time of pandemic by covid-19.

Eating behavior is considered important in education and good eating habits help to prevent health problems. It is also important to consider that eating behavior has a multifactorial influence, since it has a relation of dependence with parental, cultural and socioeconomic environment.

\section{References}

Blissett, J., Farrow, C., \& Haycraft, E. (2019). Relationships between observations and parental reports of 3-5 year old children's emotional eating using the Children's Eating Behaviour Questionnaire. Appetite, 141, 104323.

Carnell, S., Pryor, K., Mais, L. A., Warkentin, S., Benson, L., \& Cheng, R. (2016). Lunch-time food choices in preschoolers: Relationships between absolute and relative intakes of different food categories, and appetitive characteristics and weight. Physiology \& Behavior, 162, 151-160.

Carroll, N., Sadowski, A., Laila, A., Hruska, V., Nixon, M., Ma, D., \& Haines, J. (2020). The Impact of COVID-19 on Health Behavior, Stress, Financial and Food Security among Middle to High Income Canadian Families with Young Children. Nutrients, 12(8), 2352.

Coelho, C., Afonso, L., \& Oliveira, A. (2017). Práticas parentais de controlo alimentar: relação com o peso da criança. Acta Portuguesa de Nutrição, 9, 6-11.

Cole, N. C., An, R., Lee, S.-Y., \& Donovan, S. M. (2017). Correlates of picky eating and food neophobia in young children: a systematic review and metaanalysis. Nutrition Reviews, 75(7), 516-532.

Courtney, D., Watson, P., Battaglia, M., Mulsant, B. H., \& Szatmari, P. (2020). COVID-19 Impacts on Child and Youth Anxiety and Depression: Challenges and Opportunities. The Canadian Journal of Psychiatry, 65(10), 688-691.

Creswell, J. 'I Just Need the Comfort': Processed Foods Make a Pandemic Comeback. New York: The New York Times. 7 April 2020. Available online: https://https://www.cssiculinary.com/i-just-need-the-comfort-processed-foods-make-a-pandemic-comeback (accessed on 18 April 2021).

Dalrymple, K. V., Flynn, A. C., Seed, P. T., Briley, A. L., O’Keeffe, M., Godfrey, K. M., \& Poston, L. (2019). Associations between dietary patterns, eating behaviours, and body composition and adiposity in 3-year-old children of mothers with obesity. Pediatric Obesity, 15(5).

Derks, I. P. M., Sijbrands, E. J. G., Wake, M., Qureshi, F., van der Ende, J., Hillegers, M. H. J., Jaddoe, V. W. V., Tiemeier, H., \& Jansen, P. W. (2018). Eating behavior and body composition across childhood: a prospective cohort study. International Journal of Behavioral Nutrition and Physical Activity, $15(1)$.

Fernandez, C., DeJesus, J. M., Miller, A. L., Appugliese, D. P., Rosenblum, K. L., Lumeng, J. C., \& Pesch, M. H. (2018). Selective eating behaviors in children: An observational validation of parental report measures. Appetite, 127, 163-170.

Gassman-Pines, A., Ananat, E. O., \& Fitz-Henley, J., II. (2020). COVID-19 and Parent-Child Psychological Well-being. Pediatrics, $146(4)$, e2020007294.

Hossain, M. M., Sultana, A., \& Purohit, N. (2020). Mental Health Outcomes of Quarantine and Isolation for Infection Prevention: A Systematic Umbrella Review of the Global Evidence. SSRN Electronic Journal, 42, e2020038.

Hulley, S. B., Cummings, S. R., Browner, W. S., Grady, D. G. \& Newman, T. B. (2008). Delineando uma pesquisa clínica: uma abordagem epidemiológica (5th ed.). Artmed.

Instituto Brasileiro de Geografia e Estatística. (2019). PNAD Contínua 2018: educação avança no país, mas desigualdades raciais e por região persistem. https://agenciadenoticias.ibge.gov.br/agencia-sala-de-imprensa/2013-agencia-de-noticias/releases/24857-pnad-continua-2018-educacao-avanca-no-pais-masdesigualdades-raciais-e-por-regiao-persistem.

Joseph Louis, S. P., \& Tyug, T. S. (2021). Socio-demographic disparities in the eating behaviour of Malaysian children during the COVID-19 lockdown. Osong Public Health and Research Perspectives, 12(3), 196-199.

Lindsay,A.C., Sussner,K.M., Kim, J., Gortmaker, S. The role of parentes in preveting childhood obesity. Future Child. Spring 2006; 16(1):169-86.

Kininmonth, A. R., Smith, A. D., Llewellyn, C. H., \& Fildes, A. (2020). Socioeconomic status and changes in appetite from toddlerhood to early childhood. Appetite, 146, 104517. 
Research, Society and Development, v. 10, n. 17, e07101722435, 2021

(CC BY 4.0) | ISSN 2525-3409 | DOI: http://dx.doi.org/10.33448/rsd-v10i17.22435

Konings, F. P. H., Rilling, F. I. L., Medina, L. H. B., San Martín, A. G., \& Game, J. I. H. (2018). Asociación entre conducta alimentaria y estado nutricional en preescolares chilenos. Nutrición Hospitalaria, 35(5), 1049.

Ludvigsson, J. F. (2020). Systematic review of COVID-19 in children shows milder cases and a better prognosis than adults. Acta Paediatrica, 109(6), 10881095 .

Lippi, G., Henry, B. M., Bovo, C., \& Sanchis-Gomar, F. (2020). Health risks and potential remedies during prolonged lockdowns for coronavirus disease 2019 (COVID-19). Diagnosis, 7(2), 85-90.

Passos, D. R. dos, Gigante, D. P., Maciel, F. V., \& Matijasevich, A. (2015). Comportamento alimentar infantil: comparação entre crianças sem e com excesso de peso em uma escola do município de Pelotas, RS. Revista Paulista de Pediatria, 33(1), 42-49.

Pedrosa, E. N. (2017). Efeito da escolaridade dos pais sobre o estado nutricional dos filhos no Brasil. Dissertação de mestrado, Universidade Federal de Viçosa, Viçosa, MG, Brasil.

Prime, H., Wade, M., \& Browne, D. T. (2020). Risk and resilience in family well-being during the COVID-19 pandemic. American Psychologist, 75(5), 631643.

Rundle, A.G.; Park, Y.; Herbstman, J.B.; Kinsey, E.W.; Wang, Y.C. COVID-19-Related School Closings and Risk of Weight Gain Among Children. Obesity 2020, 28, 1008-1009.

Sandvik, P., Ek, A., Eli, K., Somaraki, M., Bottai, M., \& Nowicka, P. (2019). Picky eating in an obesity intervention for preschool-aged children - what role does it play, and does the measurement instrument matter? International Journal of Behavioral Nutrition and Physical Activity, 16(1).

Scaglioni, S., De Cosmi, V., Ciappolino, V., Parazzini, F., Brambilla, P., \& Agostoni, C. (2018). Factors Influencing Children's Eating Behaviours. Nutrients, 10(6), 706.

Sidor, A., \& Rzymski, P. (2020). Dietary Choices and Habits during COVID-19 Lockdown: Experience from Poland. Nutrients, $12(6), 1657$.

Spahić, R., \& Pranjić, N. (2019). Children's Eating Behaviour Questionnaire: association with BMI in children aged 3-10 years from Bosnia and Herzegovina. Public Health Nutrition, 22(18), 3360-3367.

Taylor, C. M., \& Emmett, P. M. (2018). Picky eating in children: causes and consequences. Proceedings of the Nutrition Society, 78(02), 161-169.

Viana, V., \& Sinde, S. (2012). O comportamento alimentar em crianças: Estudo de validação de um questionário numa amostra portuguesa (CEBQ). Análise Psicológica, 26(1), 111-120.

Vitorino, G. F. de A. (2018). Saberes e práticas de crianças pré-escolares relacionados ao estilo de vida: o caso de uma escola municipal. Dissertação de mestrado, Universidade Federal de Pernambuco, Recife, PE, Brasil.

Wardle, J., Guthrie, C. A., Sanderson, S., \& Rapoport, L. (2001). Development of the Children's Eating Behaviour Questionnaire. Journal of Child Psychology and Psychiatry, 42(7), 963-970.

Wolstenholme, H., Kelly, C., Hennessy, M., \& Heary, C. (2020). Childhood fussy/picky eating behaviours: a systematic review and synthesis of qualitative studies. International Journal of Behavioral Nutrition and Physical Activity, 17(1). 